$$
\begin{aligned}
& \text { رويانشناسى درخت عرعر، يكى تونه مهاجم از ايران }
\end{aligned}
$$

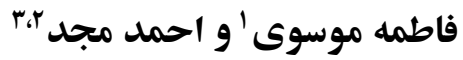

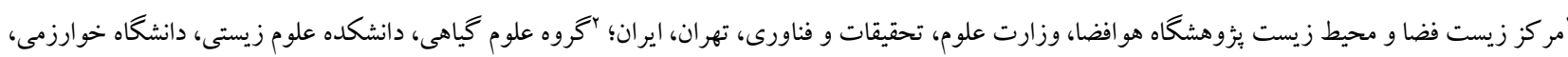

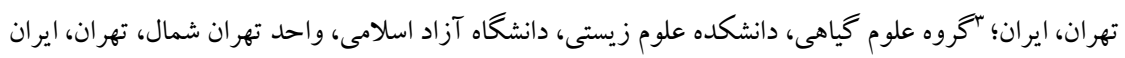

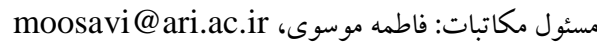

جكيده. تيره تكك نيا Simaroubaceae متعلق به راسته Sapindales شامل rاس سرده و 1.9 كونه است. كونه Ailanthus altissima يا درخت برديس، كونه اى

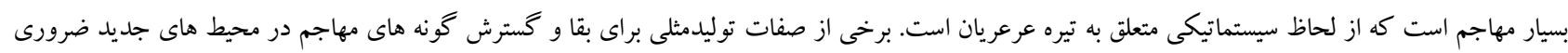

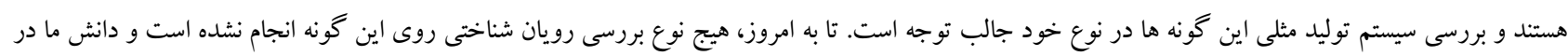

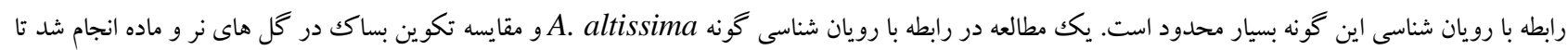

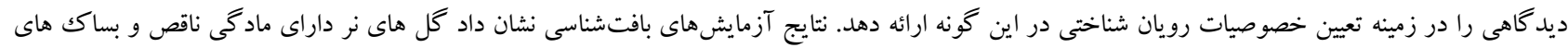

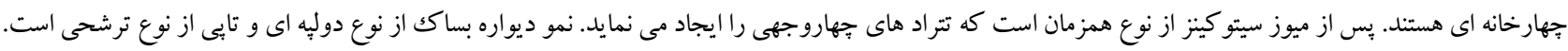

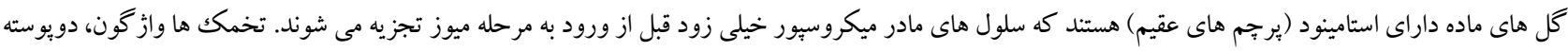

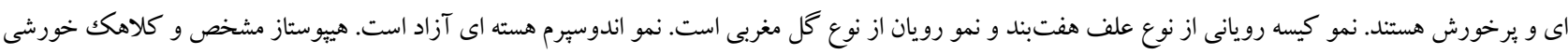

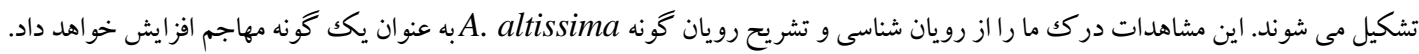

$$
\text { وازههاى كليدى: تخمك، درخت برديس، بساك، رويان، هييوستاز }
$$

\title{
The embryology of Ailanthus altissima (Simaroubaceae): an invasive species from Iran
}

\section{Fateme Mousavi ${ }^{1} \&$ Ahmad Majd ${ }^{2,3}$}

${ }^{1}$ Space Biology and Environment Center, Aerospace Research Institute, Ministry of Science, Research and Technology,

Tehran, Iran; ${ }^{2}$ Department of Plant Sciences, Faculty of Biological Sciences, Kharazmi University, Tehran, Iran;

${ }^{3}$ Department of Biology, Faculty of Biological Sciences, Islamic Azad University, North Tehran Branch, Tehran, Iran Correspondent author: Fateme Mousavi, moosavi@ari.ac.ir

\begin{abstract}
Simaroubaceae is a monophyletic family in the order Sapindales with 22 genera and 109 species. Ailanthus altissima (Mill) Swingle, also known as the tree of heaven, is a highly invasive species, which systematically belongs to Simaroubaceae. Reproductive characteristics are essential for the deployment and maintenance of invasive species in new environments and examination of the reproductive system of these species is interesting. To date, no embryological investigations had been directed to A. altissima and our knowledge on the embryology of this species was very limited. A study was carried out on the embryology of A. altissima and the comparison of anther development in male and female flowers in order to gain insights into defining embryological features in this species. According to the results of histological analysis, male flowers have rudimentary gynoecia and anthers are tetrasporangiate. Cytokinesis in meiosis is simultaneous resulting in tetrahedral tetrads. Anther wall development follows the dicotyledonous type and the tapetum is secretory. Female flowers have staminodes and microspore mother cells are degraded too early before entering the course of meiosis. Ovules are anatropous, bitegmic, and crassinucellate. The development of the embryo sac follows the polygonum type. Embryos follow the Onagrad type. The endosperm development is nuclear type. A well-developed hypostase is present and a nucellar cap is formed. These observations will advance our understanding of embryology and embryo anatomy in A. altissima as an invasive species.
\end{abstract}

Keywords. anther, embryo, hypostase, ovule, tree of heaven 
نازا، كوجکك، جهار لوبه و پارانشيمى فاقد هر گونه كيسه گردهاى و ورده هستند )

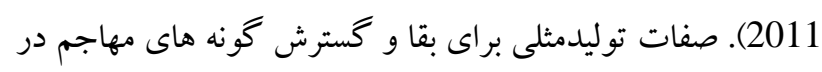
محيط هاى جديد ضرورى است (Correia et al., 2014).

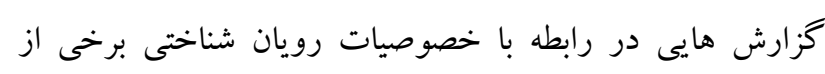

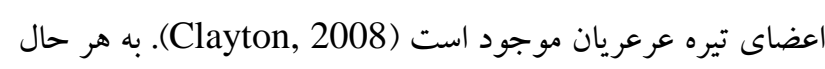

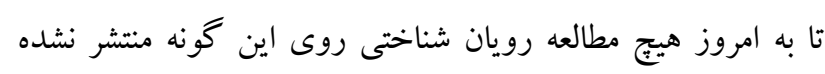

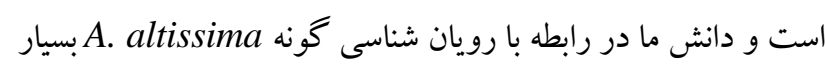

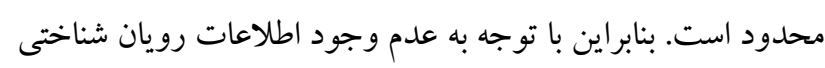

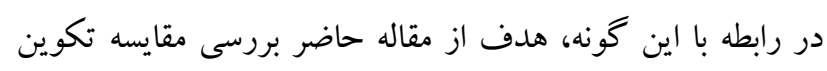

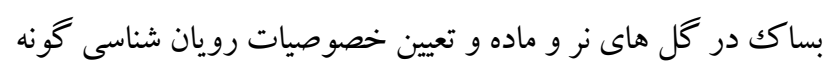

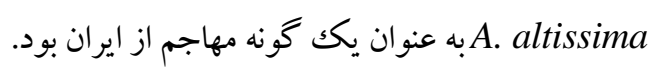

\section{مواد و روش ها}

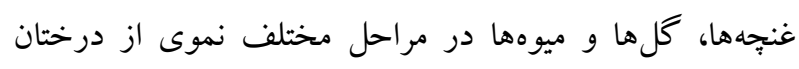

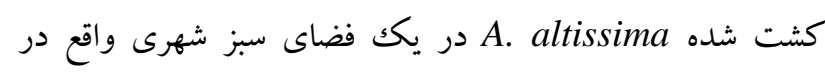

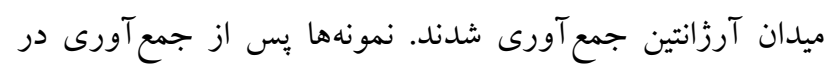

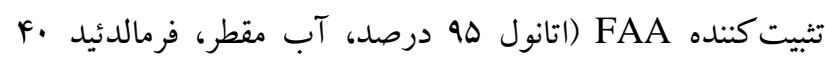

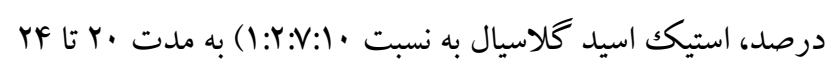

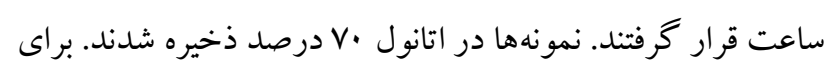

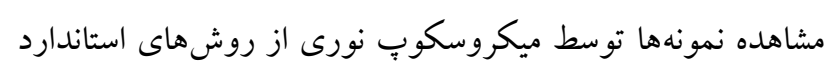

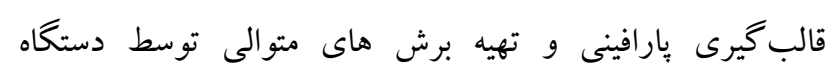

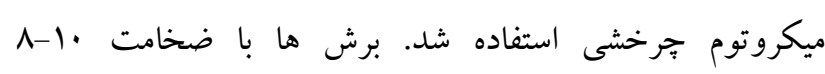

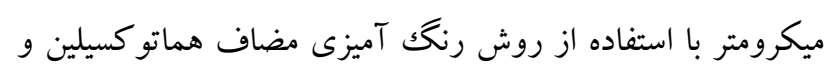

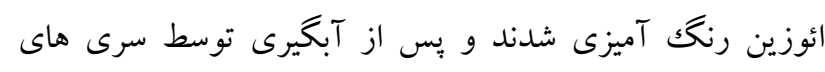

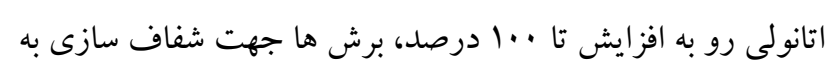

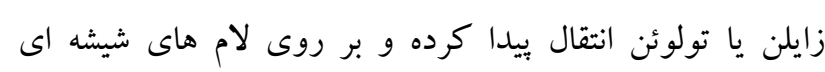

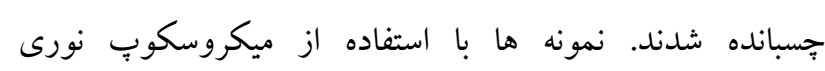
مورد بررسى قرار گرفتند و عكسبردارى از (Olympus BH-2) لام هاى مناسب توسط يكك دوربين ديجيتال انجام گرفت.

\section{تنتإج}

تكوين بساكى در كل هاى ماده

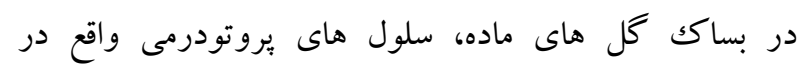

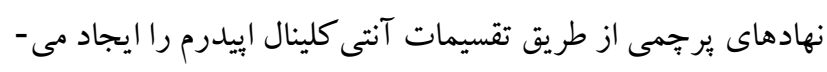

مقام

Simaroubaceae متيره عرعلق به راسته Simdales

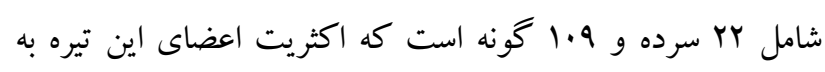
طور گسترده در مناطق گرمسيرى و نيمه گرمسيرى توزيع شده اند، اين تيره با حضور كواسينوئيدها و متابوليت هاى ثانويه كه مسئول طيف وسيعى از فعاليت هاى بيولوزيكى هستند شناخته مى شود. (Alves et al., 2014) كل ها به طور كلى دوجنس يا تكك جنس و اغلب همراه بقايايى از

اندام زايشى جنس مخالف هستند (Hua \& Thomas, 2008).

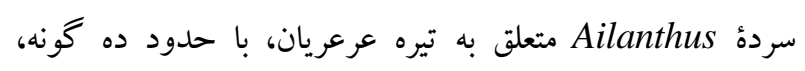

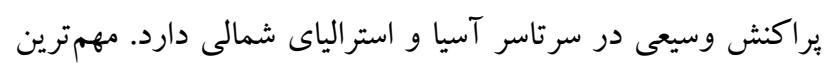
كونه ها در اين سرده عبارتند از: Ailanthus altissima (Mill) Ailanthus Ailanthus excelsa (Roxb.) ،Swingle وAilanthus vilmoriniana Ailanthus triphysa ،integrifolia .(Kundu \& Laskar 2010 Baily, 1964) Ailanthus giraldii كونه A. altissima (Mill) Swingle كه به عنوان درخت يرديس يا عرعر هم شناخته مى شود در حال حاضر به سرعت در

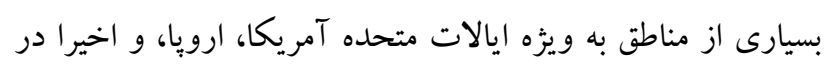
ايران كسترش يافته است. درخت برديس درختى دويايه است كه آنه

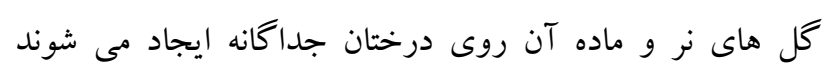
(Mousavi et al., 2016)

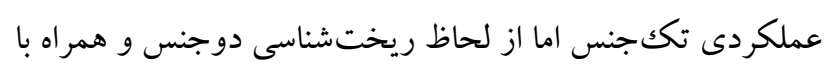

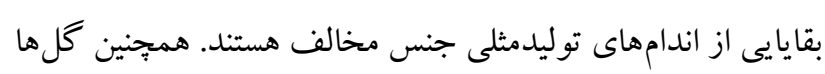

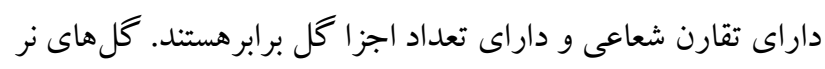

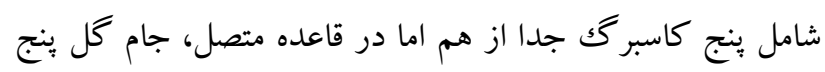

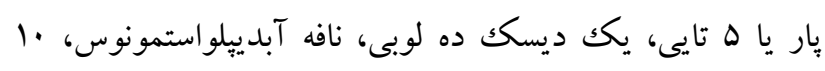

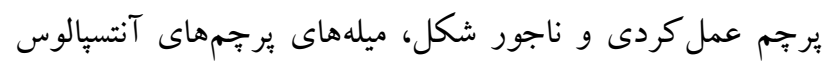

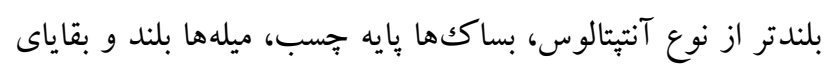

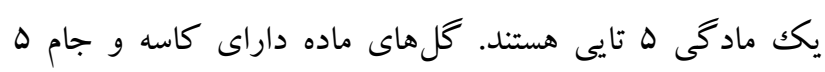

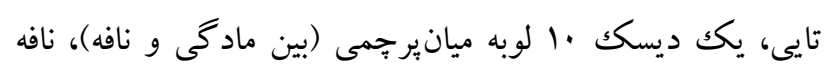

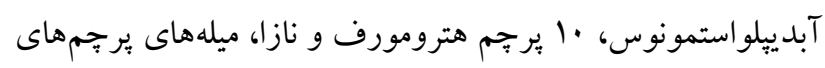

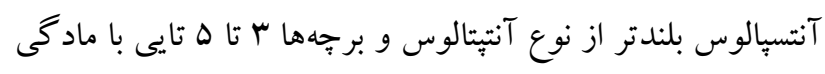

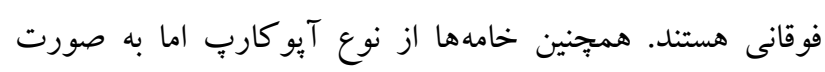

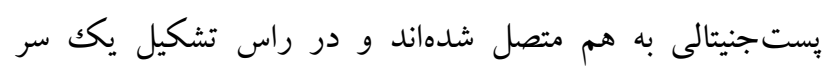

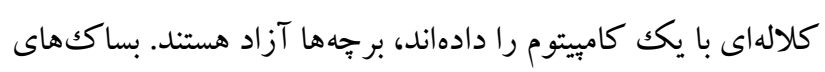


مشخص بوده و هسته به سمت قطب ميكروييلى و يا بنى تغيير مكان

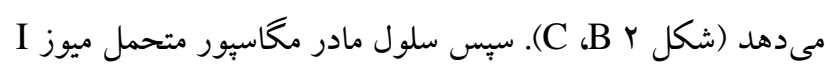
و مى شود كه به ترتيب تشكيل يكك دياد و يكك تتراد خطى از

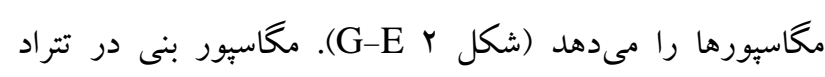
عمل كردى است و سه مخاسيور قطب سفتى تجزيه مى شوند (شكل

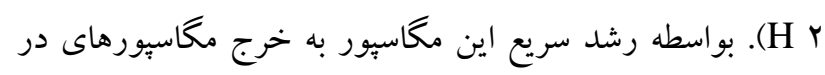

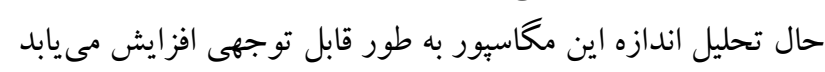

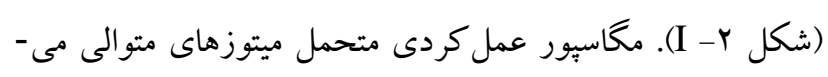

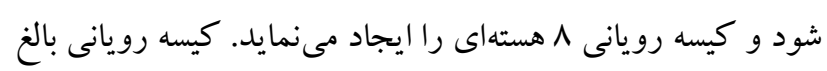
شامل سه سلول متقاطر در قطب سفتى و يا بنى، دوسلول همراه، يكك سلول تخمزا در قطب بنى و يا سفتى و دو هسته قطبى در مركز

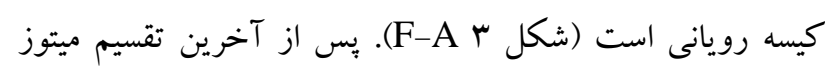

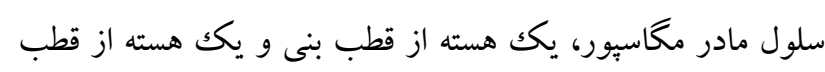
سفتى به سمت هم حركت نموده و تشكيل هسته ثانويه قطبى را

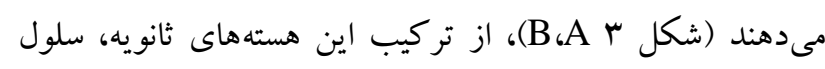

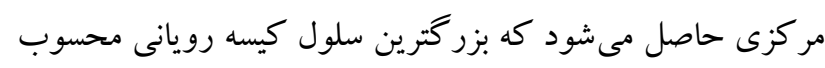

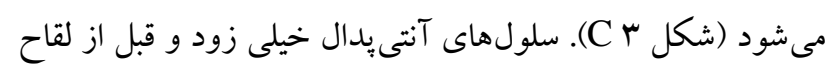

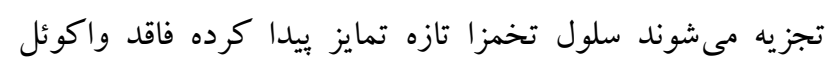

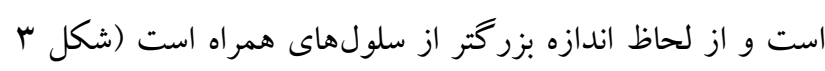

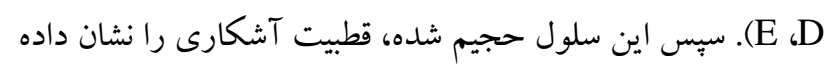

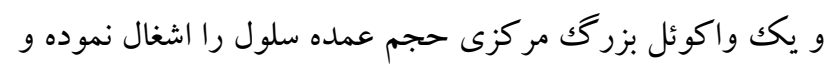

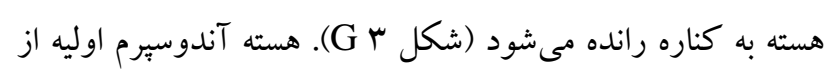
لقاح سلول مركزى با يكى از اسرِ مهاى لوله گرده تشكيل مى شوده.

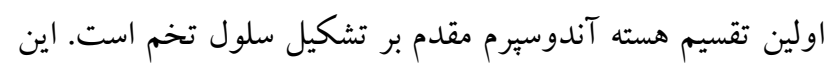
تقسيمات بدون تشكيل ديواره است و نمو آندوسيرم از نوع هسته اى آزاد است (شكل D F F). با ورود اسبرم ديخر به سلول

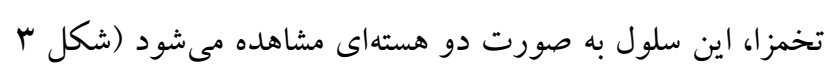

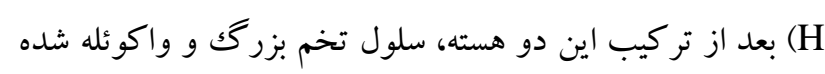

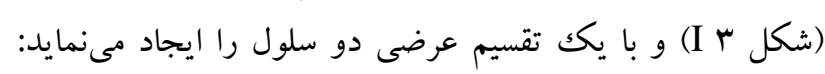

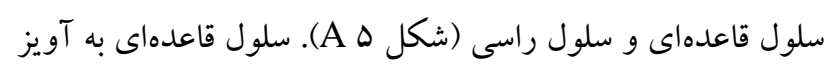

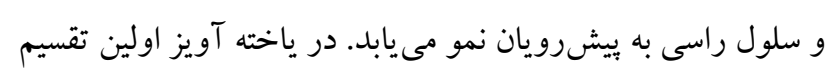

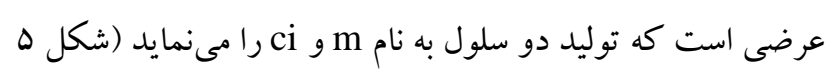
B

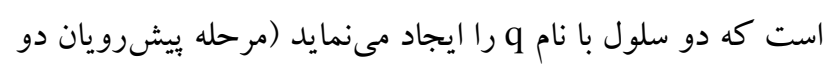

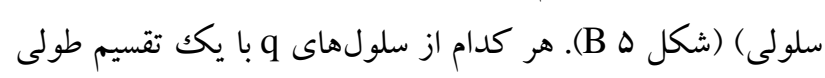

نمايند (شكل I C-A) و سلولهاى مريستم زمينه، سلولهاى

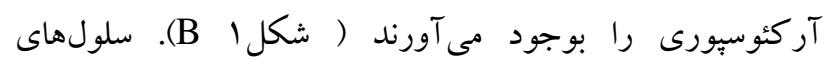

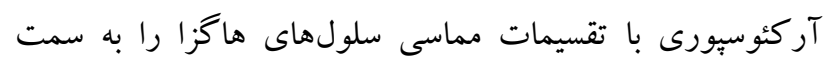

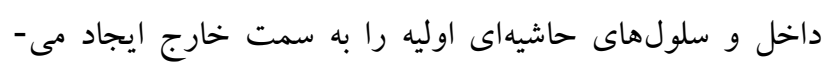

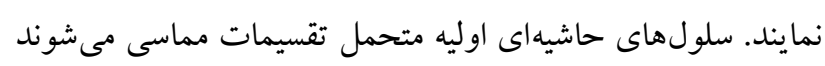

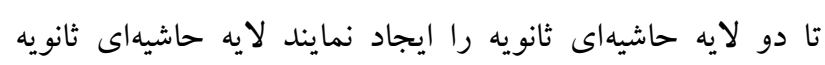
خارجى با تقسيمات مماسى و لايههاى ميانى و مكانيكى را ايجاد

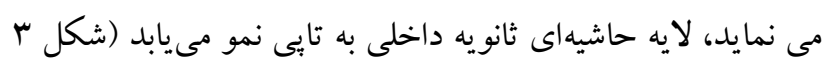

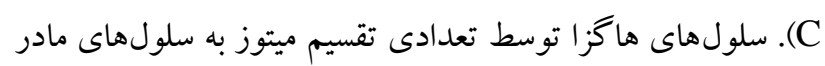

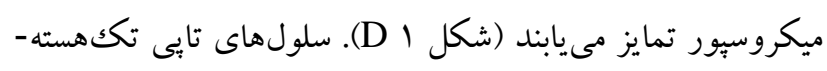

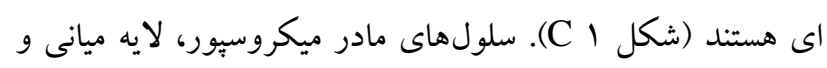

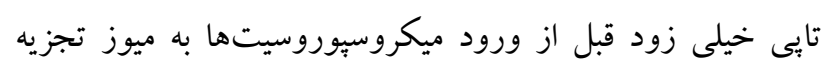

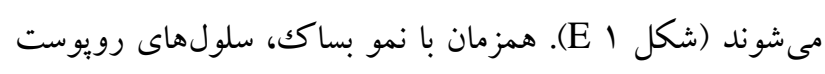

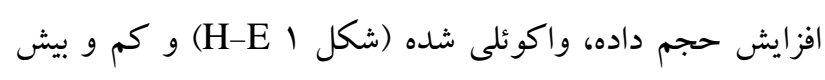

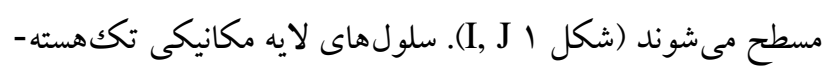

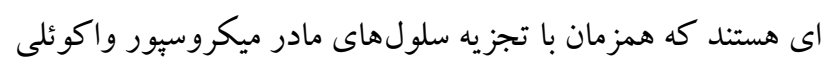

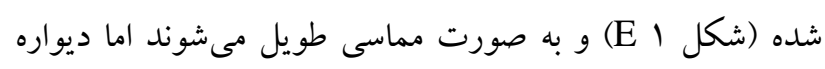

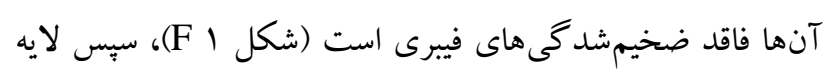

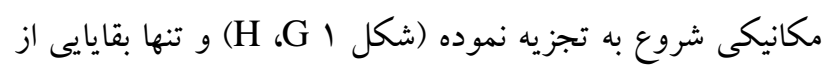

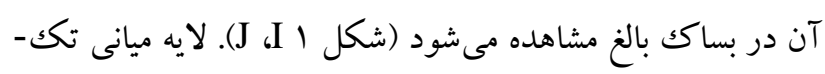

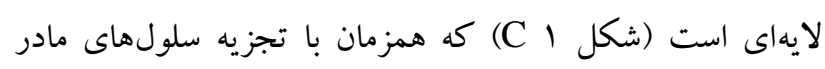

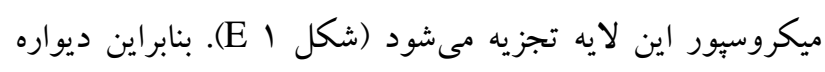

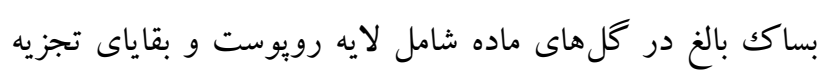

$$
\text { شده ساير لايهها است (شكل IJ (J). }
$$

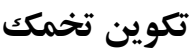

مكاسيورزايع، معاكامت زايع و رويان شناسى در كل هاى

ماده

سلولهاى آركئوسيورى اوليه در زير بِروتوردم و در منقطه يريمورديوم راسى خورش، يكك سلول حاشيهاى (يوشاننده) و يكك إنك

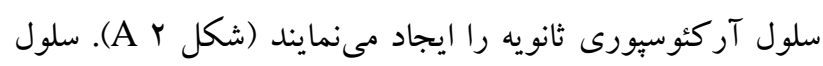
حاشيهاى متحمل تقسيمات بيشترى شده و تشكيل يكك بافت

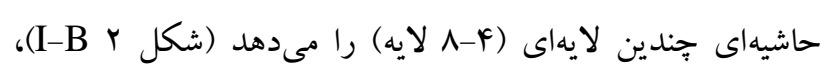

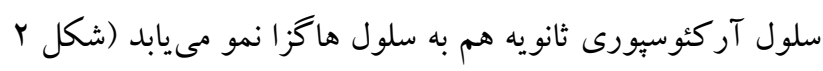

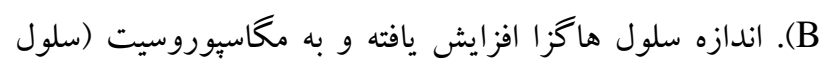

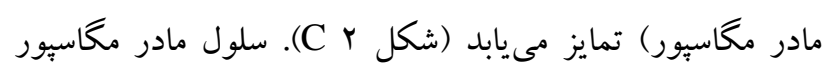

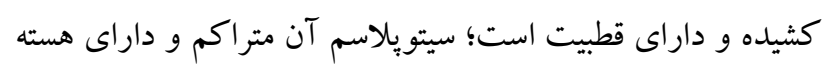




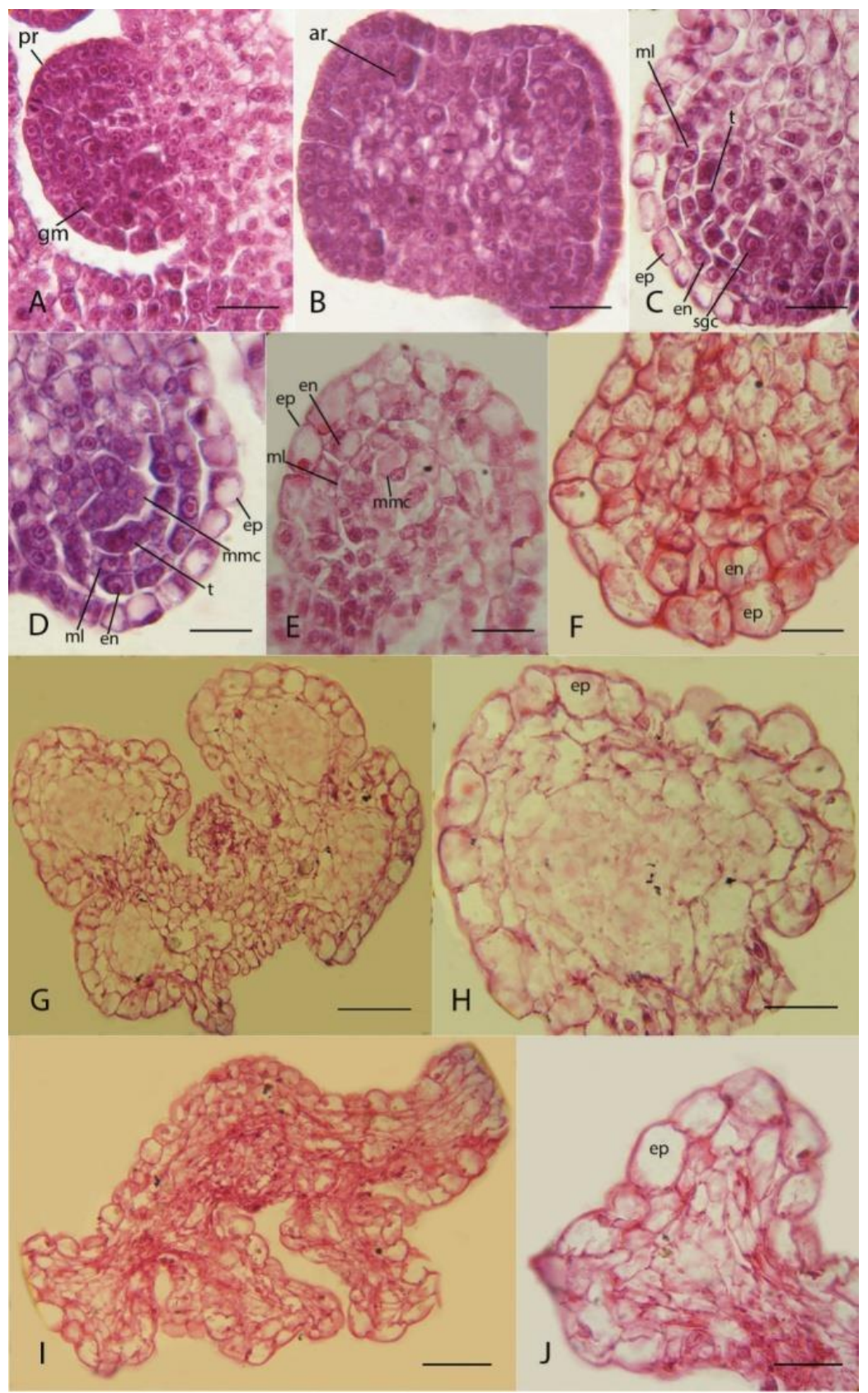

شكل ا - نمو بساك در گلهاى ماده (Ailanthus altissima). A. يريمورديوم يرجمى با سلولهاى بيش يوست و مريستم زمينه. B. برش عرضى بساك جوان با

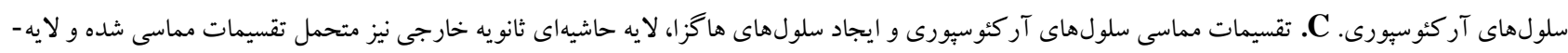

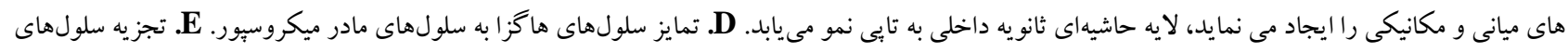

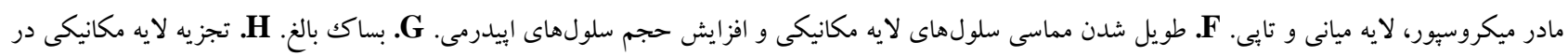

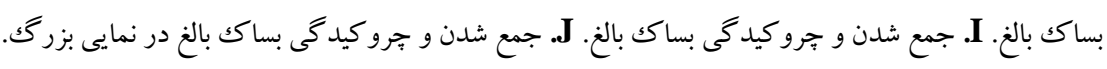

Fig. 1. Anther development in female flowers (Ailanthus altissima). A. Stamen primordium with ground meristem and protodermal cells. B. Cross section of a young anther with archeosporial cells. C. Periclinal division of archeosporial cells and producing sporogenous cells, the endothecium and the middle layer are derived from the periclinal division of the outer secondary parietal cells (Dicotyledonous type). D. Differentiation of sporogenous cells into microspore mother cells. E. Degeneration of microspore mother cells, middle layer and tapetum. F. Tangentially elongation of endothecial cells and epidermal cells enlargement. G. Mature anther. H. Degeneration of endothecial cell layer in mature anther. I, J. shrinkage and collapse of the anther locules. Abbreviations: pr, protodermis; gm, ground meristem; ar, archesporial cell; ep, epidermis; en: endothecium; ml, middle layer; sgc, sporogenous cell; t: tapetum; mmc, microsporemother cell. Scale bars: $40 \mu \mathrm{m}$. 


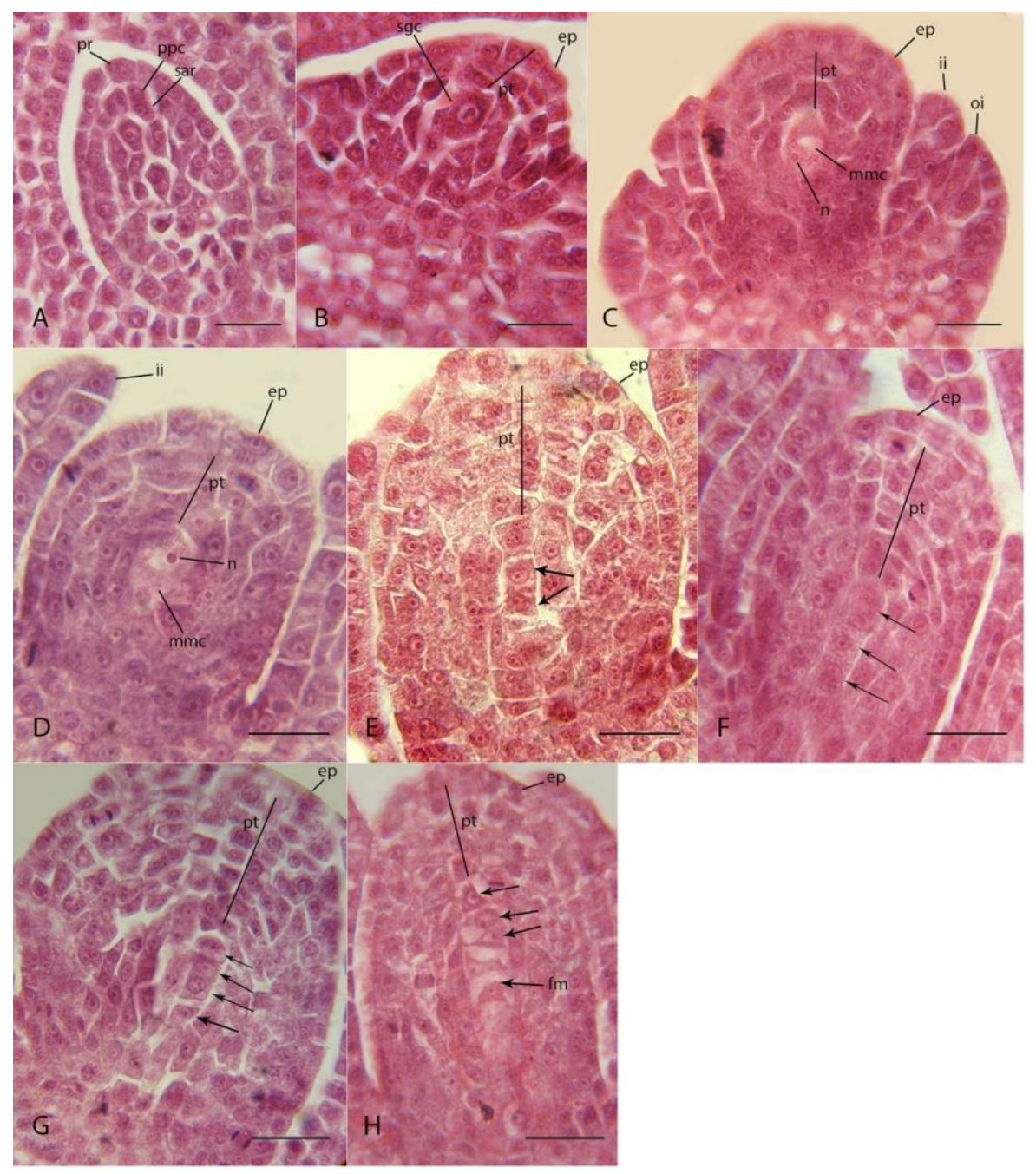

شكل ץ- مكاسيورزايى در گل هاى ماده (Ailanthus altissima). A. يريمورديوم تخمكى با سلولهاى يروتودرمى و تقسيم سلول آركئوسبورى اوليه و ايجاد دو

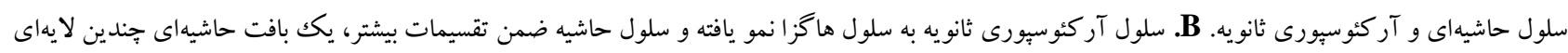

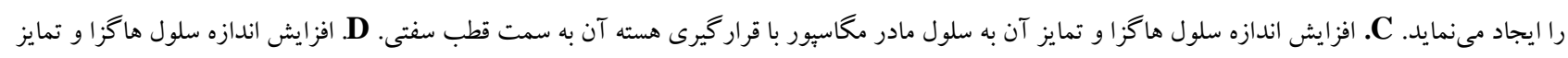

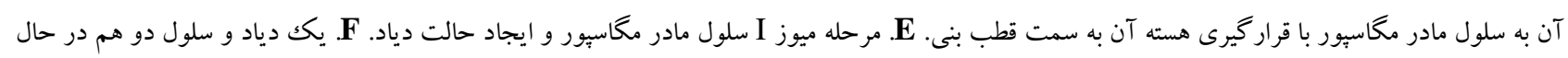

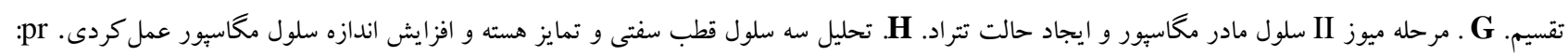

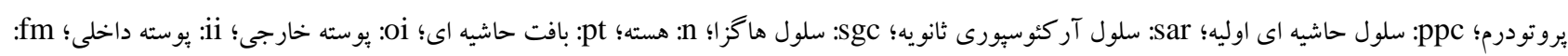

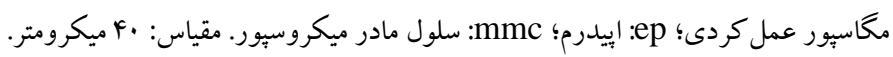

Fig. 2. Megasporogenesis in female flowers (Ailanthus altissima). A. An ovule primordium with protodermal cells and division of primary archeosporial cell to produce secondary archeosporial cell and parietal cell. B. Development of secondary archeosporial cell into sporogenous cell, more division of sporogenous cell led to formation of a multilayerparietal tissue. C. The enlargement of sporogenous cell and its differentiation into megaspore mother cell with the position of the nucleus towards the micropolar pole. D. The enlargement of sporogenous cell and its differentiation into megaspore mother cell with the position of the nucleus towards the chalazal pole. E. Meiosis I of megaspore mother cell and producing dyad state. F. A dyad, the second cell is dividing. G. Meiosis II of megaspore mother cell and producing liner tetrads. H. Degeneration of the three megaspores on the micropolar pole and the development of the chalazal one into the megagametophyte (functional megaspore). Abbreviations: pr, protoderm; ppc, primary parietal cell; sar, secondary archesporial cell; sgc, sporogenous cell; n, nucleus; pt, parietal tissue; oi, outer integument; ii, inner integument; fm, functional megaspore; ep, epidermis; mmc, microsporemother cell. Scale bars: $40 \mu \mathrm{m}$. 


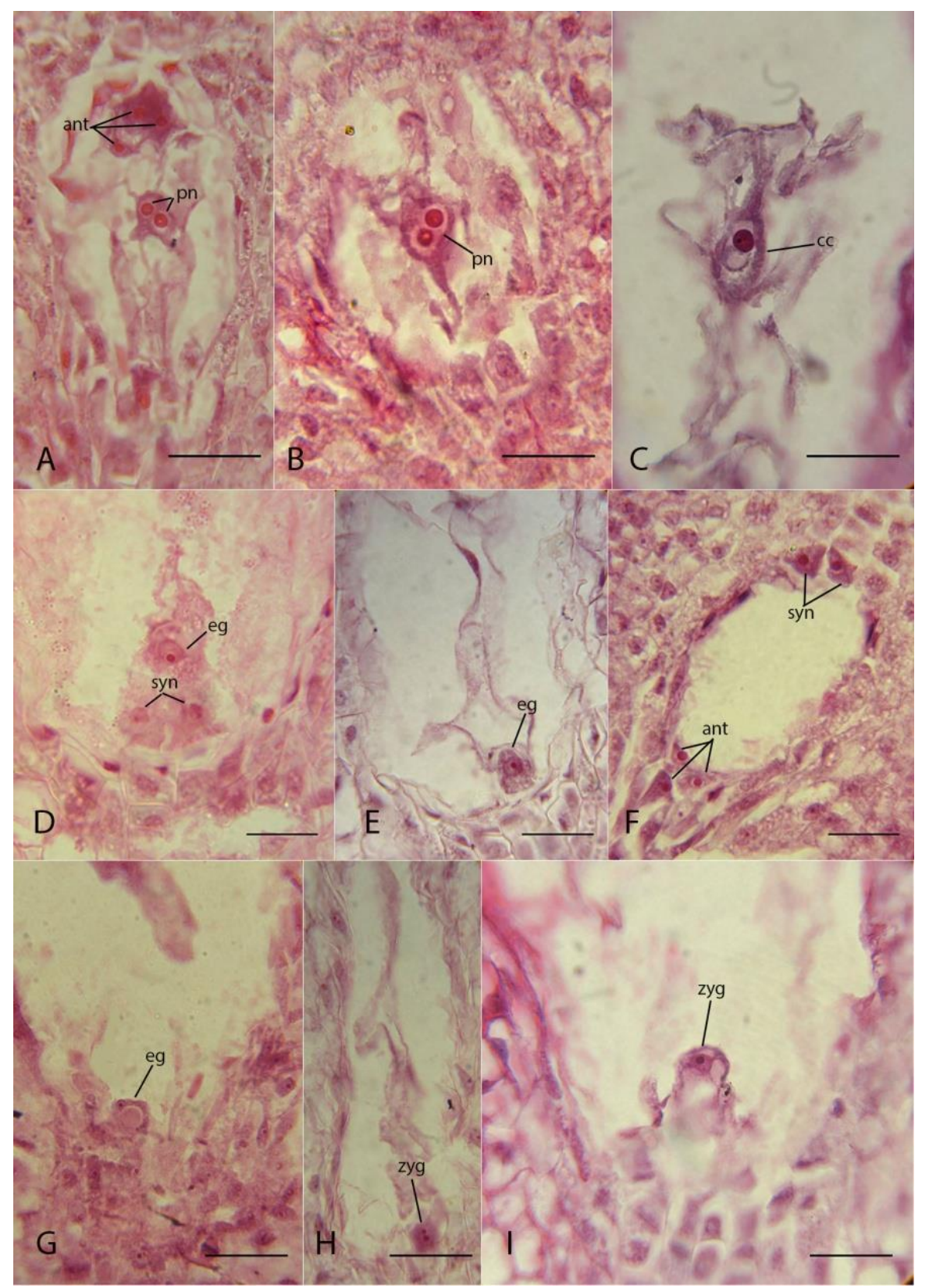

شكل بـ- مكاكامتزايى در كل هاى ماده (Ailanthus altissima). A. كيسه رويانى با هسته هاى قطبى قبل از آميزش سيتويلاسمها و سه سلول آنتى يدال در قطب

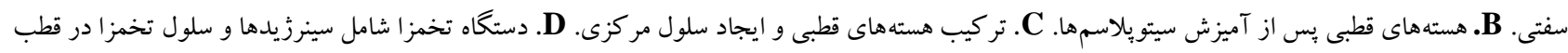

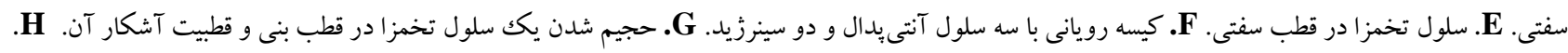

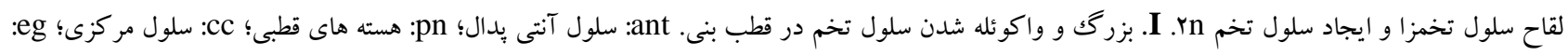

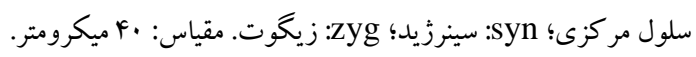

Fig. 3. Megagametogenesis and fertilization in female flowers (Ailanthus altissima). A. Embryo sac with polar nuclei and three antipodal cells before the fusion of cytoplasm. B. Polar nuclei after the fusion of cytoplasm. C. The fusion of two polar nuclei and the formation of a diploid central cell. D. The egg apparatus with two synergids and an egg cell on the micropolar pole. E. An egg cell at the chalazal pole. F. Embryo sac with three antipodal cells and two synergids. G. Egg cell enlargement and polarization at the chalazal pole. H. The fertilization of the egg cell and the formation of the zygote (2n). I. The enlargement and vacuolation of zygote at the chalazal pole. Abbreviations: ant, antipodal cell; pn, polar nuclei; cc, central cell; eg, egg cell; syn, synergid; zyg, zygote. Scale bars: $40 \mu \mathrm{m}$. 


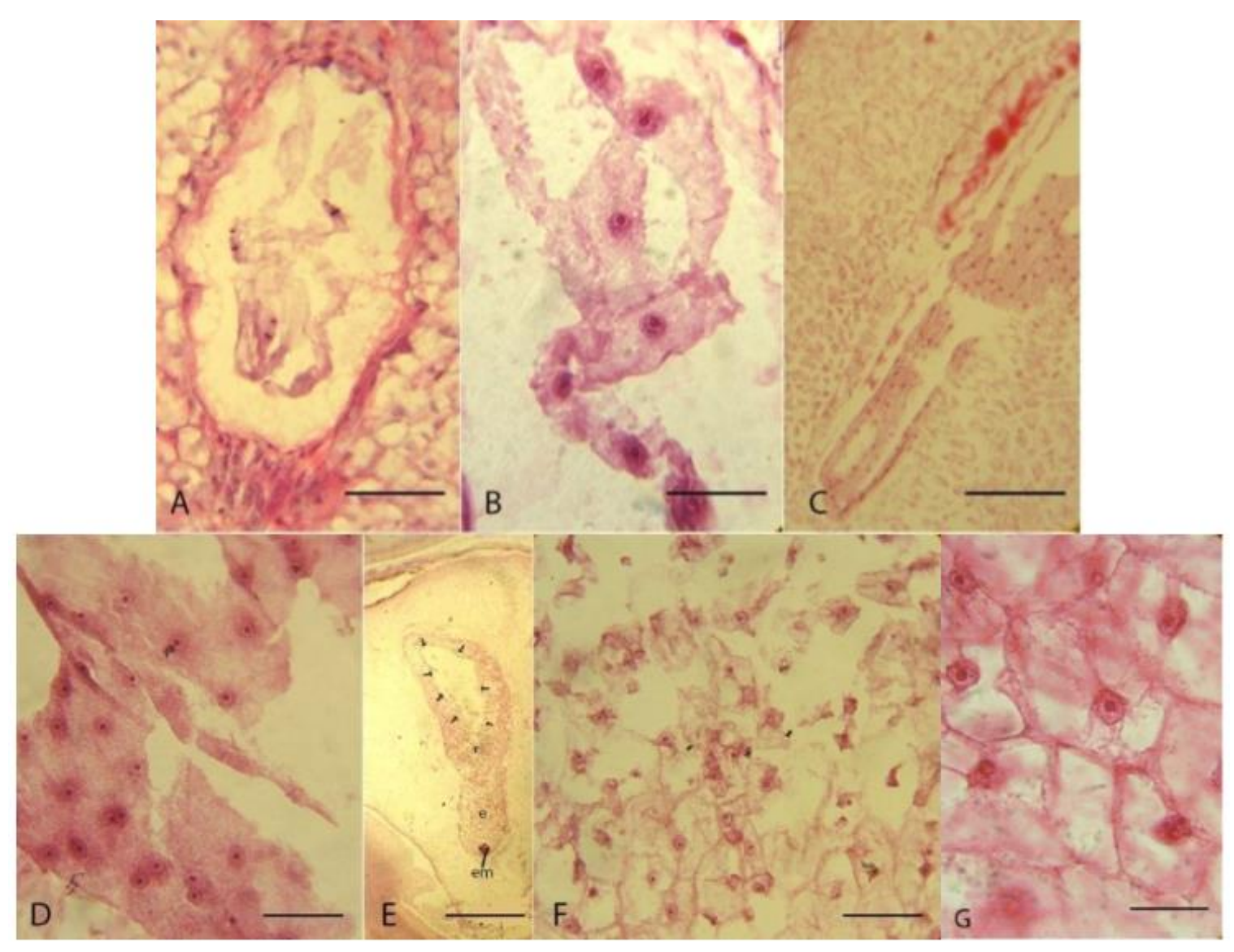

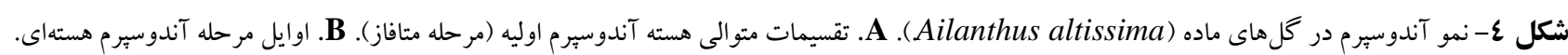

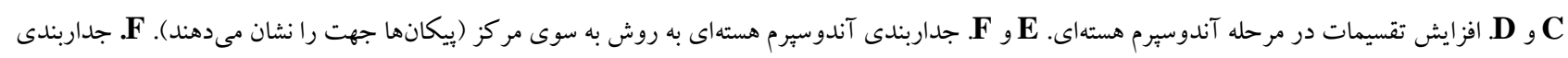

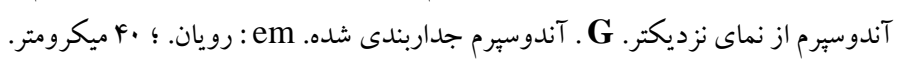

Fig. 4. Endosperm development in female flowers (Ailanthus altissima). A. Repeated divisions of the primary endosperm nucleus (metaphase phase). B. Early stages of nuclear endosperm development. C, D. The increase of divisions at the nuclear endosperm. E, F. Wall formation and cellularization of endosperm in a centripetal manner. (Arrows indicate the direction of cellularization). G. Cellular endosperm. Abbreviations: em: embryo. Scale bars: 40 $\mu \mathrm{m}$.

تقسيمات و تشكيل بريمورديومهاى لِهاى، رويان وارد مرحله گذر

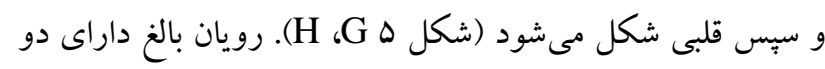

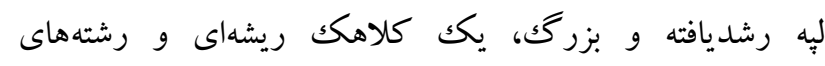

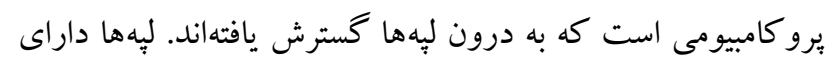

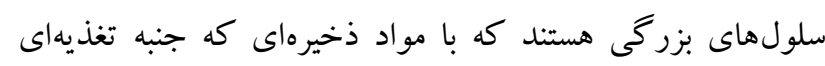

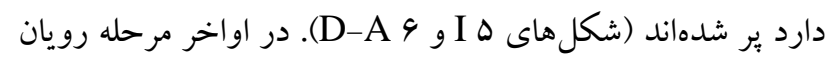

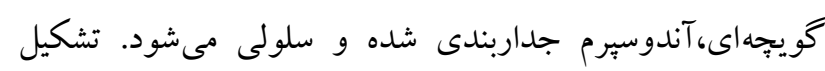

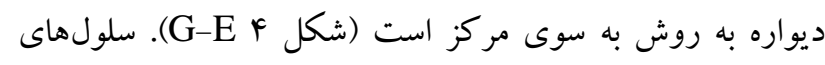

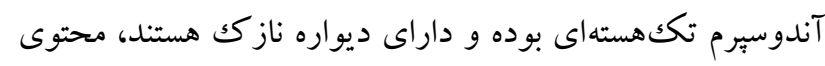

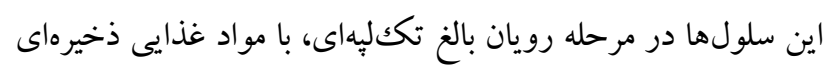

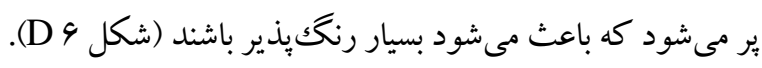

عمود بر جهت اولين تقسيم، ييش رويان جهارسلولى را ايجاد مى-

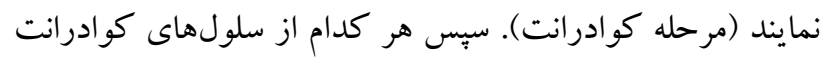

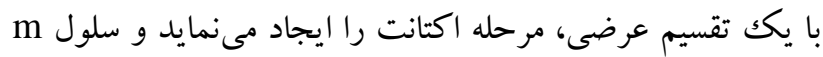

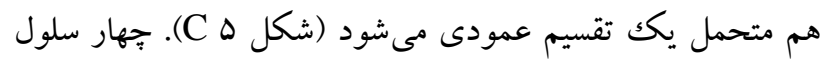

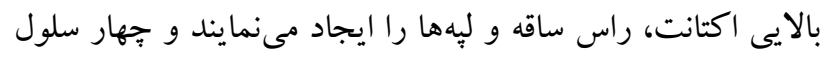

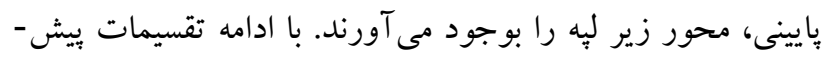

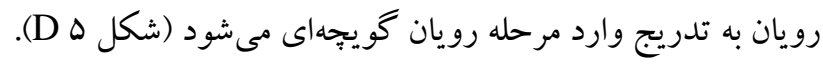

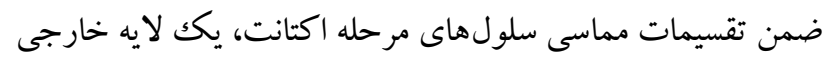

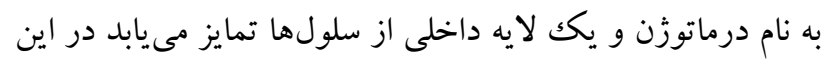

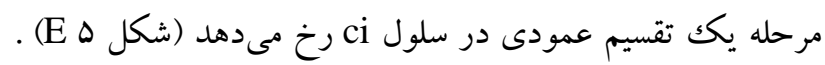

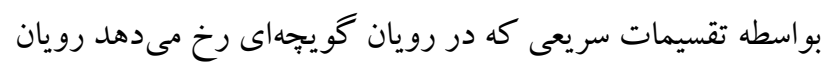

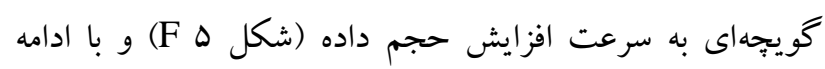


مادر ميكروسبور از نوع همزمان، تترادهاى ميكروسيور از نوع

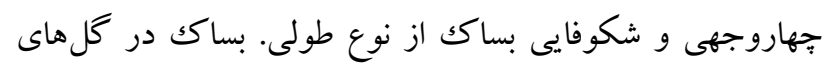

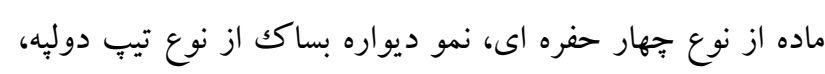

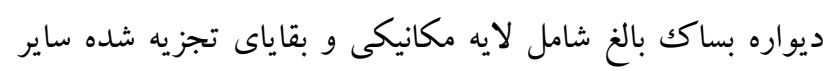

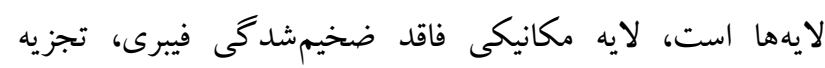

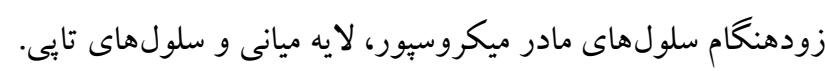

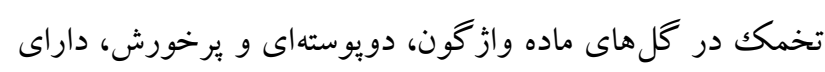

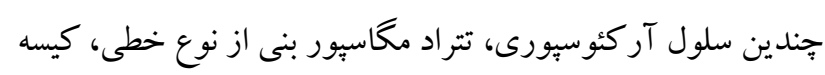

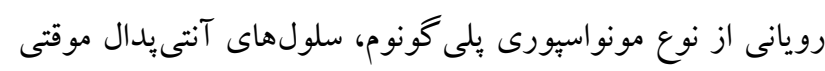

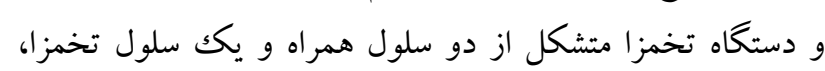

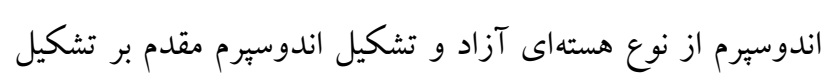

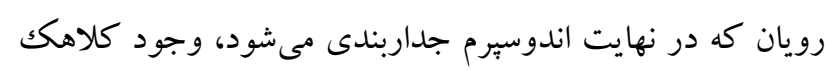

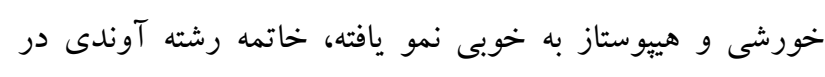

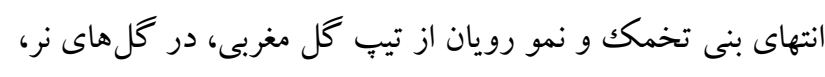
تخمك هاى ناقص داراى جندين سلول آركئوسبورى كه بـ بس از خارج شدن از خالت مريستمى به سرعت دستخوش تجزيه و تحليل

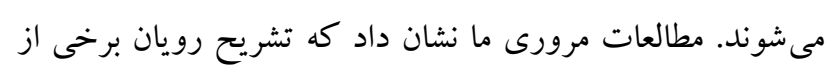

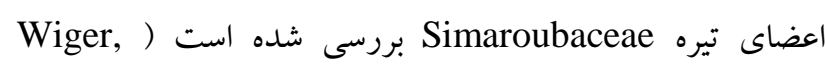

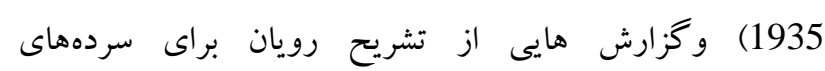
Nair \& ) Samadera ،Narayana, 1957) Ailanthus و (Nair \& Sukumaran, 1960) Brucea ،(Joseph 1957 (Pfeiffer, 1912) Leitneria

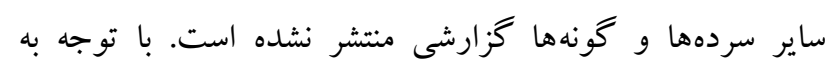

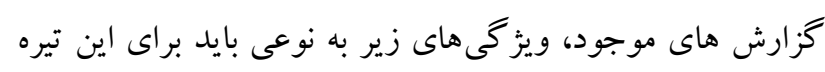

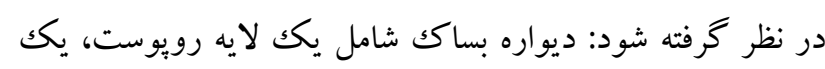

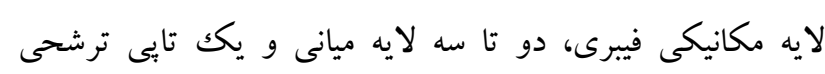

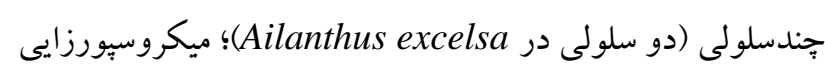

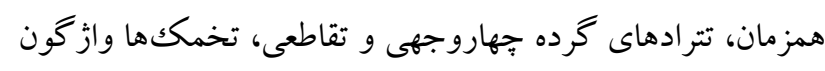

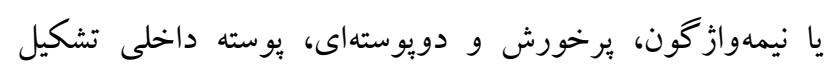

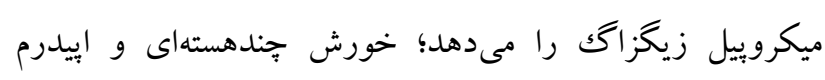
خورشى ضمن تقسيم يك ككلاهك خورشى را رايجاد مى زئمايد،

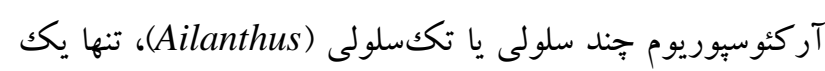
سلول آركئوسيورى نمو مى يابد؛ تترادهاى مخاسيورها در آرايش

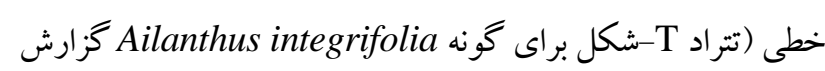

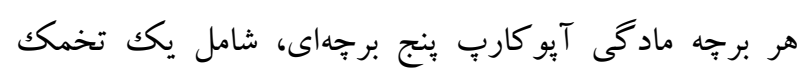

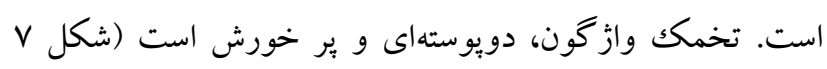
D

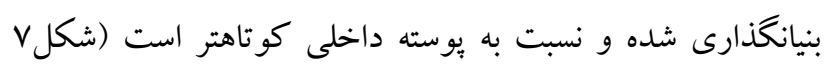
(D-A

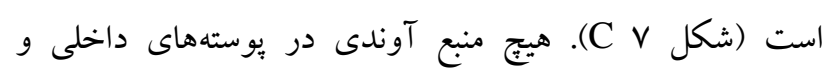
خارجى مشاهده نمى شود اما در طول مرحله تتراد مكاسبور، رشته آوندى بندى تمايز مىيابد كه تنها به محل بن كسترش مى ميابد.

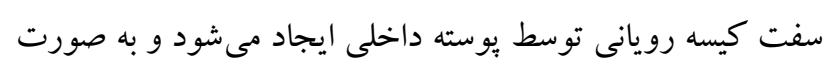
زيكزاگك است (شكل G V). هر دو بوسته در تشكيل بوشش دو دانه

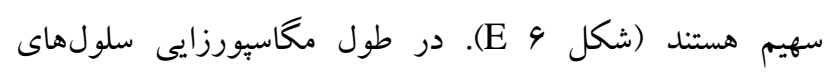
رويوست خورش به صورت مماسى تقسيم شده و يك كلاهك

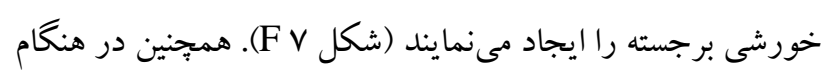

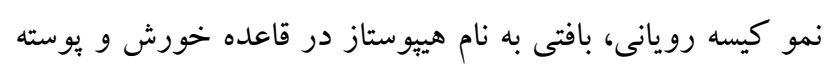

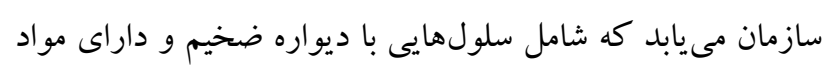

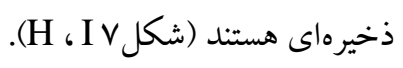

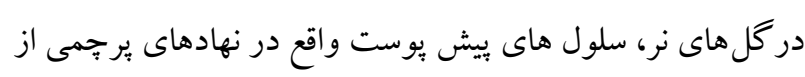
طريق تقسيمات شعاعى رويوست را ايجاد مىنمايند (شكل . 1)

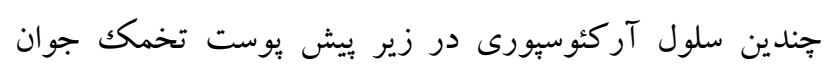

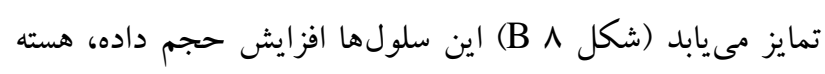

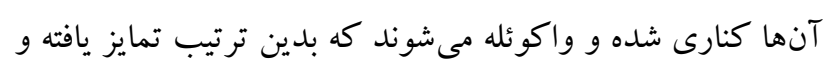

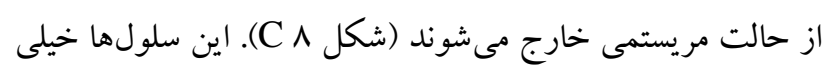

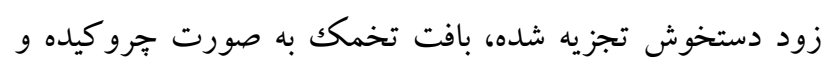

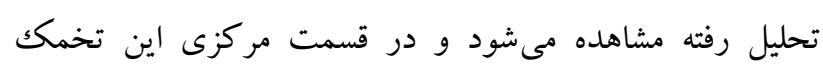
ناقص، حفره كوجكى ايجاد مىشود (شكل ^ ^ (D).

A. altissima مطالعات بافت شناسى اندام هاى توليدمثلى گونه

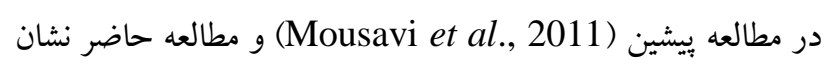
داد كه خصوصيات رويان شناختى اين گونه به شرح زير است:

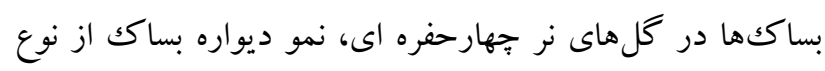

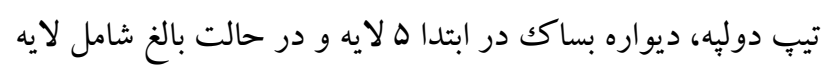
مكانيكى فيبرى و لايه بشرهاى است، لايههاى ميانى تجزيه مى -

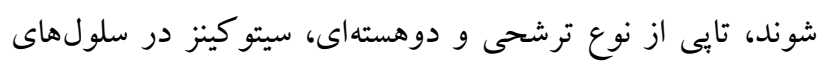




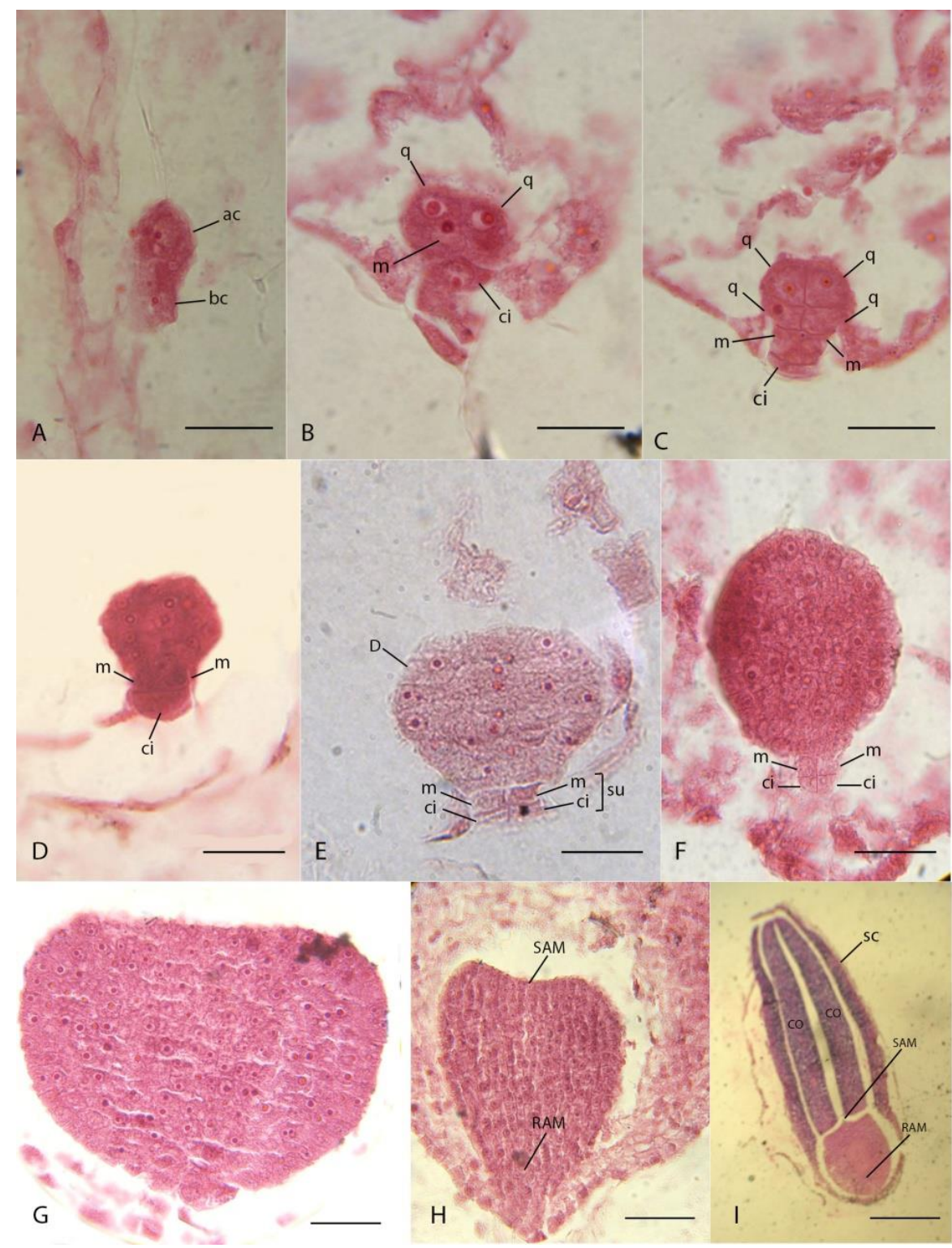

شكل 0- نمو رويان در كلهاى ماده (Ailanthus altissima). A.تقسيم عرضى سلول تخم و ايجاد دو سلول راسى و قاعدهاى. B. تقسيم عمودى ياخته راسى و

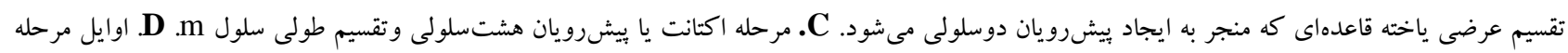

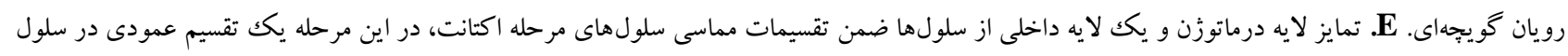

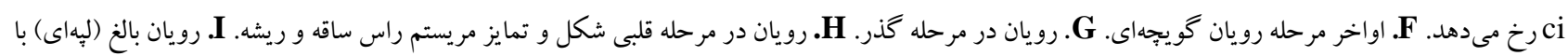

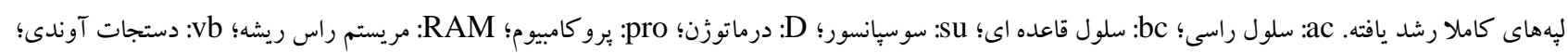

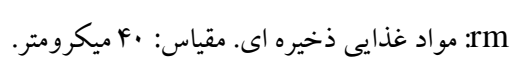

Fig. 5. Embryo development in in female flowers (Ailanthus altissima). A. The transverse division of the zygote produces two cells. B. The apical cell divides vertically and gives rise to a two-celled proembryo, the basal cell divides transversely into two cells, ci and $\mathrm{m}$. C. octant stage (8-celled proembryo) and vertical division of cell $\mathrm{m}$. D. early globular embryo stage. E. Periclinal division of octant gives rise to dermatogens cell layer and an internal cell layer, at this stage, a vertical division occurs in ci. F. Late globular embryo stage. G. Transitional stage embryo. I. Heart stage embryo; shoot apical meristem (SAM) and root apical meristem (RAM) become specified at this stage. J. Advanced stage of seed formation (embryo cotyledonary stage). Abbreviations: ac, apical cell; bc, basal cell; su, suspensor; D, dermatogen; pro, procambium; RAM; root apical meristem; vb, vascular bundle; rm, reserve food material. Scale bars: $40 \mu \mathrm{m}$. 


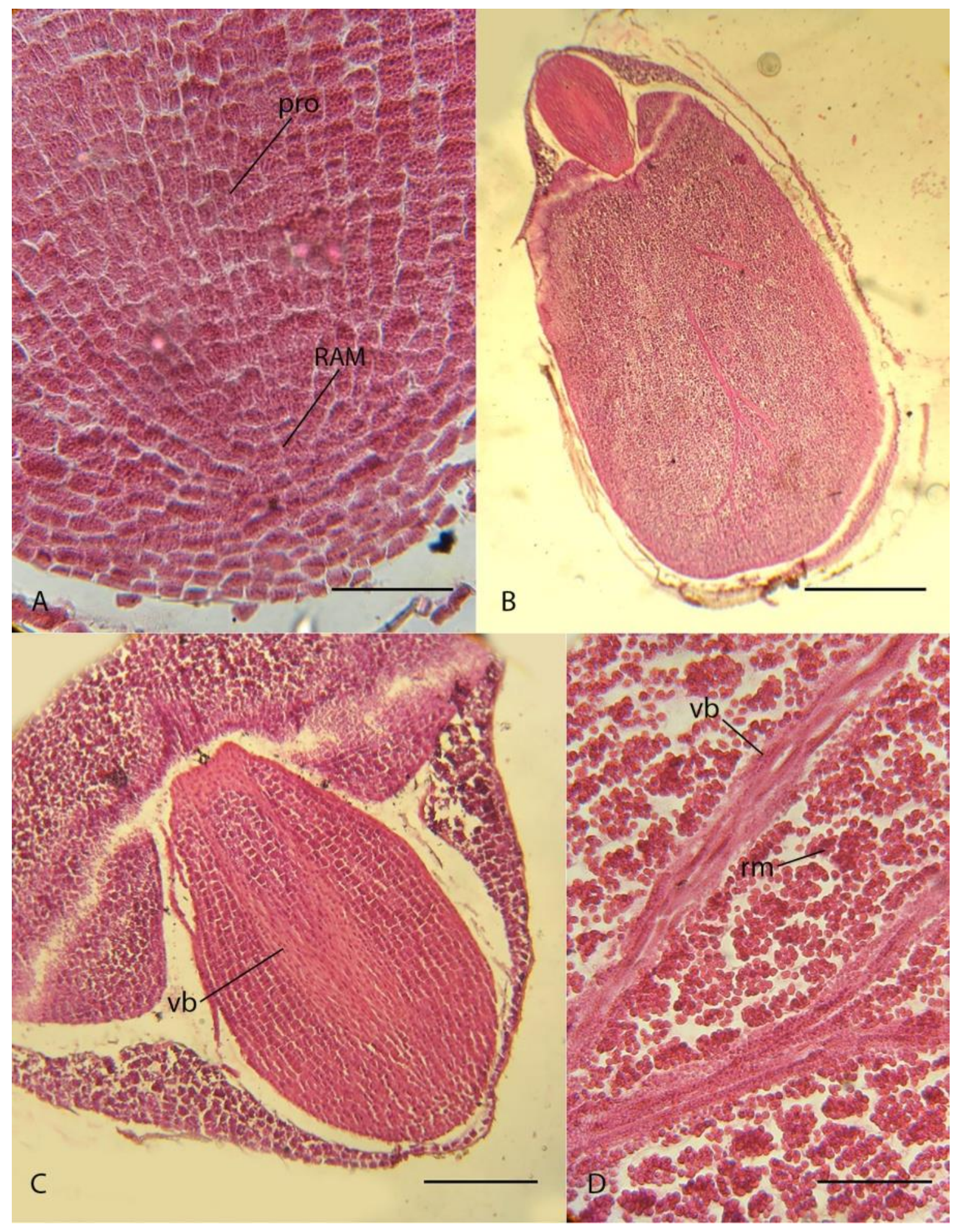

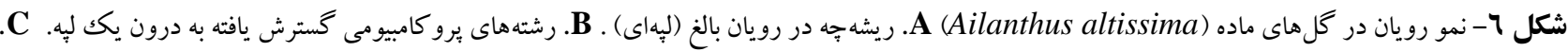

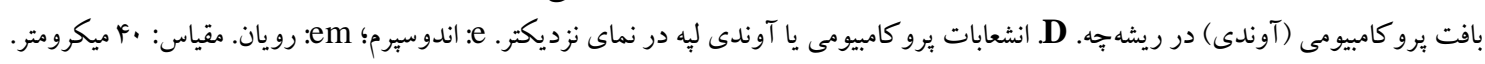

Fig. 6. Embryo development in female flowers (Ailanthus altissima). A. radicle in the embryo cotyledonary stage. B. The procambial strands extending into the cotyledon. C. Procambial tissue in the radicle. D. Procambial branches with more magnification. Abbreviations: e, endosperm; em, embryo. Scale bars: $40 \mu \mathrm{m}$. 


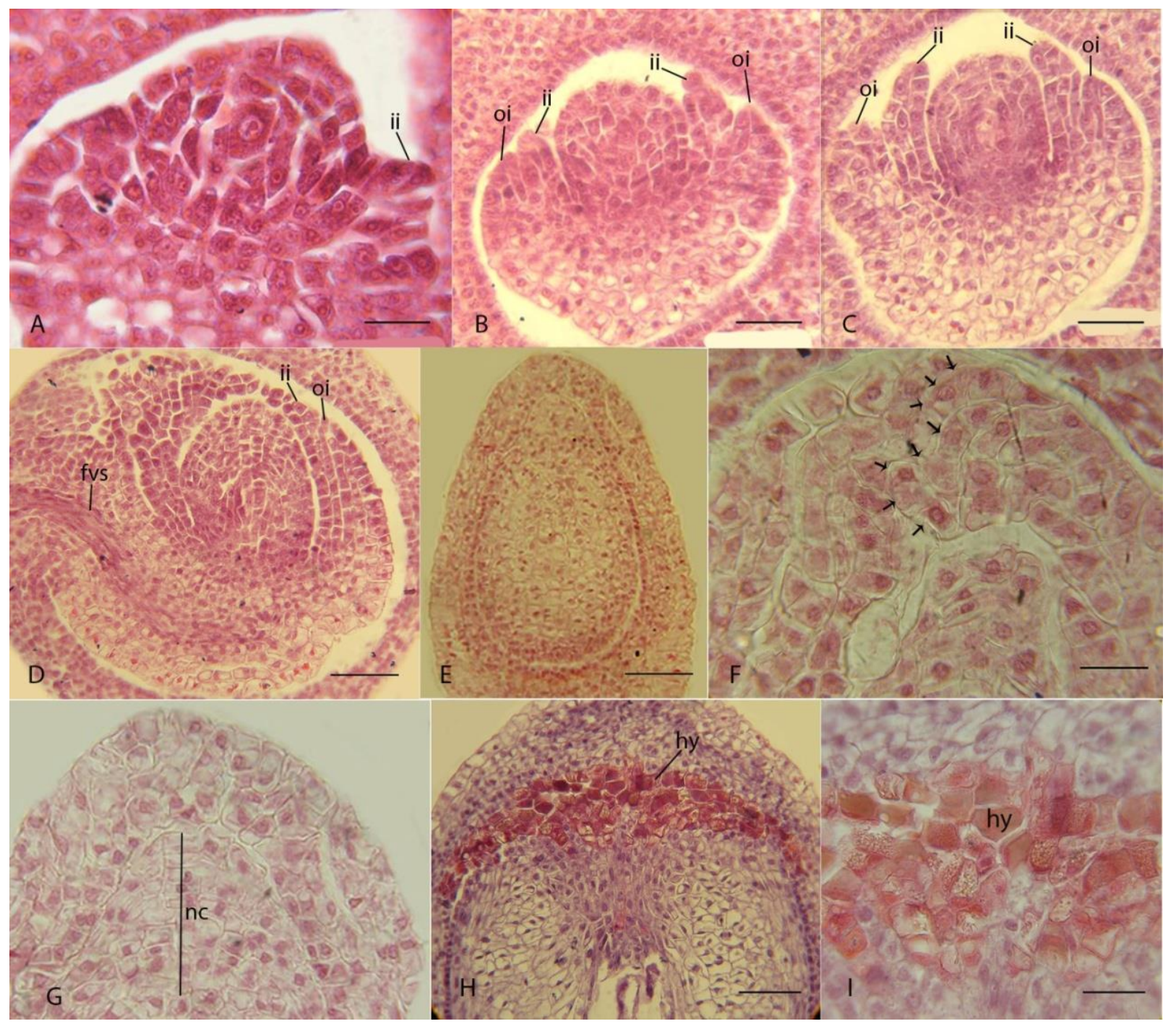

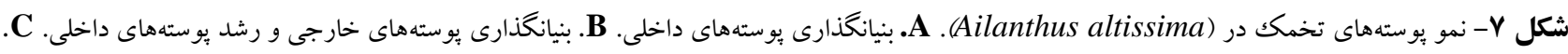

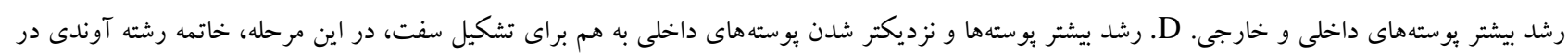

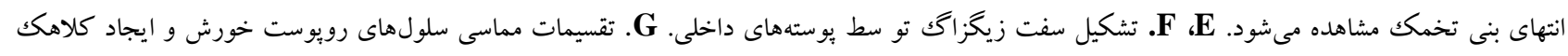

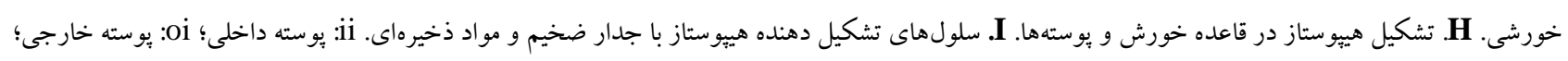

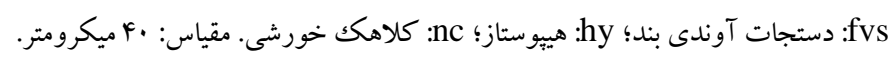

Fig. 7. The development of ovule integuments in female flowers (Ailanthus altissima). A-C. Longitudinal sections of young ovules showing inner and outer integuments initiation. $\mathbf{D}$. The growth of inner integuments around the nucellus and the formation of the micropyle. E, F. The formation of zig-zag micropyle by inner integuments. G. The periclinal divisions of the nucellar epidermis cells and formation of a prominent nucellar cap. $\mathbf{H}$. The formation of hypostase at the base of the nucellus and integuments. I. The hypostase consisting of thick-walled and reserved materials-containing cells. Abbreviations: ii, inner integument; oi, outer integument; fvs, funicular vascular bundle; hy, hypostase; nc, nucellar cap. Scale bars: $40 \mu \mathrm{m}$. 


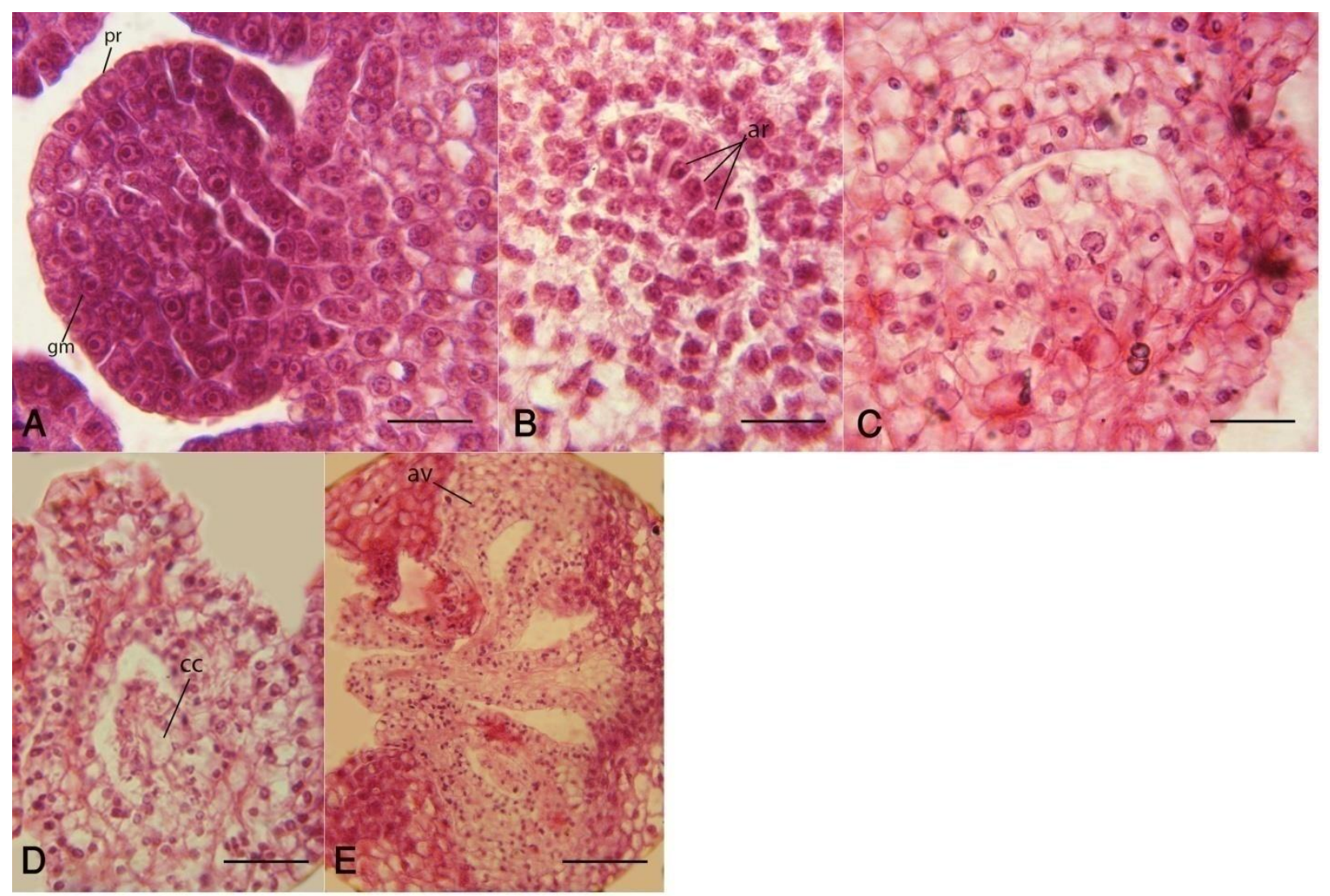

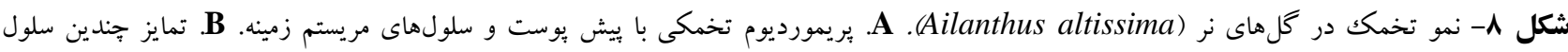

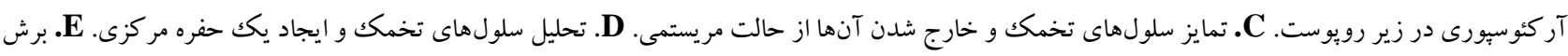

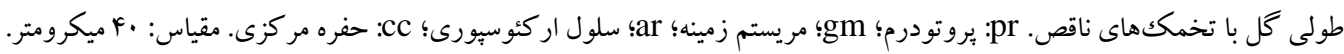

Fig. 8. Ovule development in male flowers (Ailanthus altissima). A. An Ovule primordium with protodermal and ground meristem cells. B. The differentiation of several archeosporial cells in the hypodermis. C. The differentiation of ovule cells and their exit from meristem state. D. The decomposition of ovule cells and the creation of a central cavity. E. The longitudinal section of flower, showing abortive ovules. Abbreviations: pr, protodermis; gm, ground meristem; ar, archesporial cell; cc, central cavity. Scale bars: $40 \mu \mathrm{m}$.

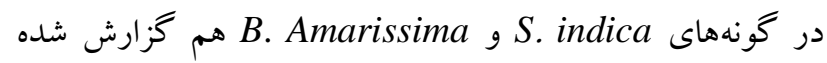

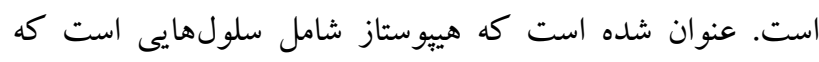

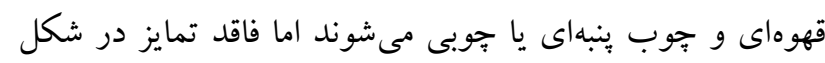

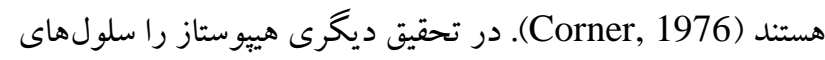

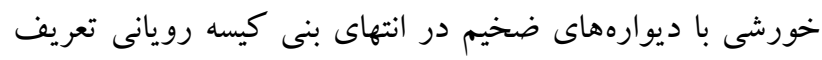

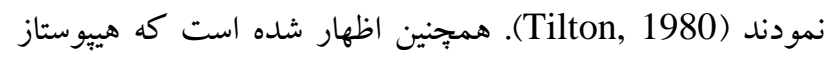
در بالاى سيستم آوندى بنى واقع مى شود و بسته به شكل قاعده

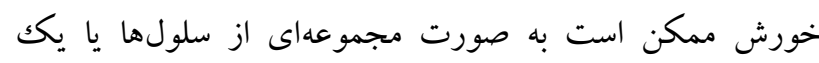

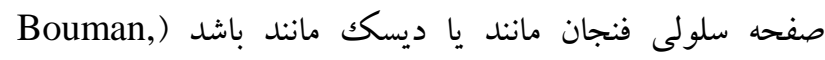
1984). مطابق با Endress (1994)،هييوستاز منطقهاى با ديوارههاى سلولى جوبى شده (ليخنينى) است كه اغلب بين دستجات

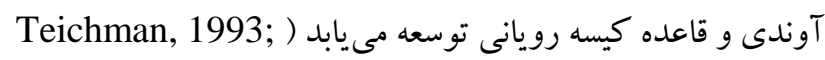
Martinsa et al., 2016
شده است)؛ مكاسيور بنى به كيسه رويانى تيب هفت بند نمو مى -

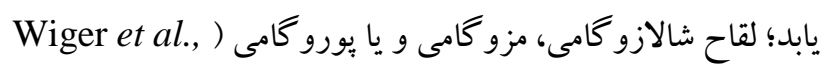

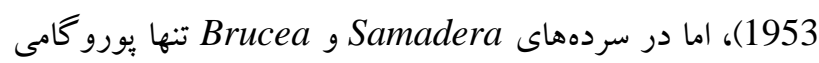

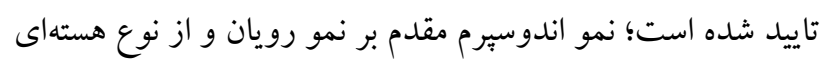

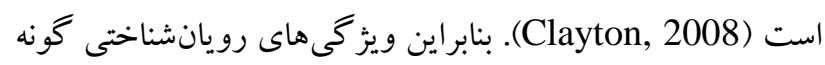
A. altissima

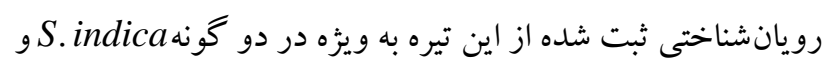
Nair \& Joseph, 1957; Nair \& ) دارد B. Amarissima .(Sukumaran 1960 به نظر مىرسد تشكيل هييوستاز كه يكك بافت ليكنينى است و در

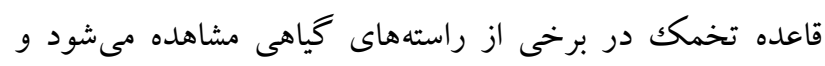

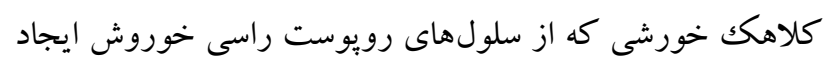
مى شود از ويز گىهاى مشخصه تخمك در در اعضاى اين تيره باشند 
Capsella Medik. ،(Brassicaceae) Alyssum L. در سردههاى ‘(Bignoniaceae) Catalpa Scopoli ‘(Brassicaceae) Heloniopsis A.Gray ،(Euphorbiaceae) Euphorbia L. Lilium L. ‘(Juncaceae) Juncus L. ‘(Melanthiaceae) Lythrum L. ،(Nelumbonaceae) Lotus L. ،(Liliaceae) Myosurus L. ‘(Lamiaceae) Mentha L. ،(Lythraceae) Sonerila Roxb. „(Rutaceae) Ruta L. „(Ranunculaceae) Veronica, (Fabaceae) Trifolium L. ،(Melastomataceae) (بارهنگيان) گزارش نمود. نمو رويان نوع گلمغربى در اعضاى L.

تيره Anacardiaceae و برخى از اعضاى تيره Rutaceae راسته Sapindales ) هم كزارش شده است ( \&

.Izmailow, 2001; Tobe, 2011; Gonzalez, 2016 حضور گل هاى تككجنس از لحاظ عمل كردى (اما از لحاظ ريختشناسى دوجنس) كه در گونه A.altissima در مطالعه حاضر هم بررسى شد، به نظر مىرسد در تيرهاى Kirkiaceae، Burseraceae ،Anacardiaceae Bachelier \& Endress, 2008) متداول باشد Sapindales Handeliodendron bodinieri (H.Lév.) براى مثال در گونه Rehder دوجنسى كاذب، يرجمها در كلهاى ماده كوجّك، مسطح و نازا

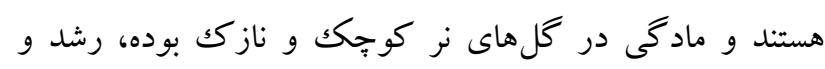
توسعه نمىيابد، تخمككهاى گل هاى نر كو جكك و جروكيده هستند و معمولا در مرحله كيسه رويانى دو سلولى شروع به تجزيه نموده، يوسته ها و خورش جذب شده و به تدريج نايديد مىشوند

.(Cao et al., 2008)

در مجموع مطالعه حاضر اطلاعات مفيدى را در رابطه باويز كى هاى رويانشناختى كونه A. altissima به عنوان يك عضو از تيره براى اولين بار ارائه داد اين اطلاعات مى تواند Simaroubaceae

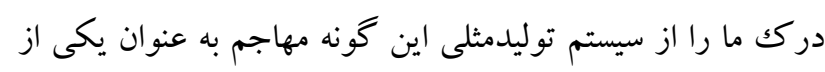
اعضاى تيره Simaroubaceae افز ايش دهد. نكارند كان از دكتر فرخ قهرمانىنزاد براى نظرات ارزشمندشان قدردانى مى كنند.
بافت در مهار رشد تهاجمى اندام مكنده اندوسيرم در قسمت بنى دانه در حال نمو نقش ايفا مى كند. در برخى از گونها، يلى ساكاريدهاى نامحلول فراوانى در ديوارههاى سلولى هيبوستاز يافت مىشوند كه اشاره به نقش اين بافت در ذخيره كربوهيدرات در طول نمو آندوسيرم دارد. بسيارى از محققين معتقدند كه عمل كرد اصلى هيبوستاز تامين مواد مغذى براى مخاكامتزايى است، هر جند محققان ديكر در رابطه با اين فرايند اختلاف نظر دارند (Pereira \& Bittencourt, 2016). هييوستاز در شمار قابل ملاحظهاى از آرايههاى Anacardiaceae هم مشاهده مىشود. Sapindales يكى از تيرههاى متعلق به راسته Anacardiaceae است كه تيره Simaroubaceae هم در اين راسته جاى دارد. براى مثال در كونه Lithraeamolleoides از تيره Anacardiaceae، در ناحيه بنى، يكك منطقه فنجانى شكل از سلولهاى يارانشيمى Carmello-Guerreiro \& ) تانندار، هييوستاز را تشكيل مىدهند .(Paoli, 2005 استقرار دستگاه تخمزا در هر دو قطب سفتى و يا بنى مىتواند

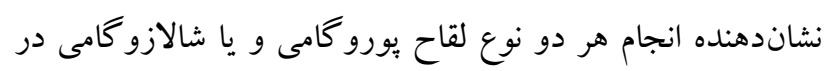

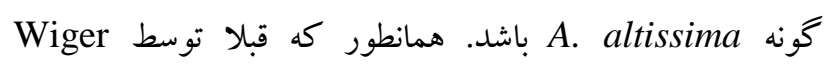
(1935) هر سه نوع لقاح شالازو گامى، مزو گامى و يورو گامى در اين تيره كزارش شده است. تخمك در گونه A. altissima از نوع وازگون و ميكروييل به صورت زيخزاخك است كه توسط يوستهاى درونى ايجاد مىشود. تخمككهاى نهاندانگان اغلب از نوع وازگ خميده، راست و نيمهواز كون مشاهده مى شوند. لوله گرده به راس بافت خورش توسط سفت هدايت مىشود كه اغلب توسط يوسته درونى يا توسط هر دو يوسته در تخمككهاى دويوسته يا توسط يكك يوسته در تخمككهاى تككيوستهاى ايجاد مى شود. سفت زيخزاگك نوع ويزٔاى از سفت است كه در آن، يوسته خارجى روى يوسته داخلى را مى يوشاند به روشى كه دو قسمت كانال سفتى در وسط تراز نيستند بلكه داراى يك شكل زيخز اگك هستند. اين نوع از سفت بيشتر در تخمككهاى خميده يافت مىشود .(Endress, 2011) نمو رويان در گونه A. altissima از تيب كل مغربى است. تيب كل مغربى نمو رويان در شكل معمول آن در تيره Onagraceae ديده مىشود. Johansen ( • (190) ها تنوع از اين تيب رويانى را 


\section{REFERENCES}

Alves, I.A., Miranda, H.M., Soares, L.A. and Randau, K.P. 2014. Simaroubaceae family: botany, chemical composition and biological activities. - Rev. Bras. Farm. 24: 481-501.

Bachelier, J.B., and Endress, P.K. 2008. Floral Structure of Kirkia (Kirkiaceae) and its Position in Sapindales. - Ann. Bot. 102: 539-550.

Baily, L.H. 1964. Manual of cultivated plants. The Macmillan Co, New York, pp: 611.

Bouman, F. 1984. The ovule. In B. M. Johri (Ed), Embryology of angiosperm. Berlin: Springer Verlag. pp: 530 .

Cao, L.M., Xia, N.H. and Deng, Y.F. 2008. Embryology of Handeliodendron bodinieri (Sapindaceae) and its systematic value: development of male and female gametophytes. - Plant. Syst. Evol. 274: 17-23.

Carmello-Guerreiro, S.M. and Paoli, A.A.S. 2005. Anatomy of the Pericarp and Seed-coat of Lithraea molleoides (Vell.) Engl. (Anacardiaceae) with Taxonomic Notes. Braz. Arch. Boil. Technol. 48: 590-610.

Clayton, J.W. 2008. Evolutionary history of Simaroubaceae (Sapindales): Systematics, biogeography and diversification. Ph.D thesis, University of Florida.

Correia, M., Castro, S., Ferrero, F., Crisóstomo, J.A. and Rodríguez-Echeverría, S. 2014. Reproductive biology and success of invasive Australian acacias in Portugal. - Bot. J. Linn. Soc. 174: 574-588.

Corner, E.J.H. 1976. The seeds of dicotyledons. 2 vols. Cambridge: Cambridge University Press. pp: 1-320.

Czapik, R. and Izmailow, R. 2001. Zygotic Embryogenesis. Structural aspects. In: Bhojwani and Soh [eds.], Current trends in the embryology of angiosperms, 197-222. The Netherlands, Dordrecht, Kluwer Academic Publishers.

Endress, P.K. 1994. Diversity and evolutionary biology of tropical flowers. Cambridge: Cambridge University Press. pp: 1-420.

Endress, P.K. 2011. Evolutionary diversification of the flowers in angiosperms. - Am. J. Bot. 98: 370-96.

Gonzalez, A.M. 2016. Floral structure, development of the gynoecium, and embryology in Schinopsis balansae Engler (Anacardiaceae) with particular reference to aporogamy. - Int. J. Plant. Sci. 177: 326338.

Hua, P. and Thomas, W.W. 2008. Simaroubaceae. - In: Flora of China: Oxalidaceae through Aceraceae. Vol.
11. Missouri. Botanical Garden Press, St. Louis. pp: 100-104.

Kundu, P., and Laskar, S. 2010. A brief resume on the genus Ailanthus: chemical and pharmacological aspects. - Phytochem. Rev. 9: 379-412.

Martinsa, F.M., Cunha-Netoa, I.L. and Pereirab, T.M. 2016. Floral morphology and anatomy of Dalechampia alata Klotzsch ex Baill. (Euphorbiaceae), with emphasis on secretory structures. - Braz. J. Biol. 76: 233-244.

Mousavi, F., Rezanejad, R., Majd, A. and Irian, S. 2010. Flower and Fruit morphology in Aianthus. altissima.J. Develop. Biol. 7: 25-32.

Mousavi, F., Rezanejad, F., Majd, A. and Irian, S. 2011. Flower structure and anther and pollen development $\mathrm{n}$ Aianthus altissima (Simaroubaseae). - J. Sci. (Kharazmi University) 10: 1033-1046.

Mousavi, F., Majd, A., Shahali, Y., Ghahremaninejad, F., Kardar, G. and Pourpak, Z. 2016. Pollinosis to tree of heaven (Ailanthus altissima) and detection of allergenic proteins: a case report. - Ann. Allergy. Asthma. Immunol. 116: 374-375.

Nair, N.C. and Joseph, T.C. 1957. Floral morphology and embryology of Samadera indica. - Bot. Gaz. 119: 104-115.

Nair, N.C. and Sukumaran, N.P. 1960. Floral morphology and embryology of Brucea amarissima. Bot. Gaz. 121: 175-185.

Narayana, L.L. 1957. Embryology of two Simaroubaceae. - Curr. Sci. 26: 323-324.

Pereira, E.J. and Bittencourt, N.S. 2016. Comparative ovule ontogeny in some members of the Tabebuia alliance (Bignoniaceae). - Int. J. Plant. Sci. 177: 481497.

Pfeiffer, W.M. 1912. The morphology of Leitneria floridana. - Bot. Gaz. 53: 189-203.

Teichman, I.V. 1993. Development and structure of the seed of Ozoroa paniculosa (Anacardiaceae) and taxonomic notes. - Bot. J. Linn. Soc. 111: 463-470.

Tilton, V.R. 1980. Hypostase development in Ornithogalum caudatum (Liliaceae) and notes on other types of modifications in the chalaza of angiosperm ovules. Can. J. Bot. 58: 2059-2066.

Tobe, H. 2011. Embryological evidence supports the transfer of Leitneria floridana to the family Simaroubaceae. - Ann. Mo. Bot. Gard. 98: 277-293.

Wiger, J. 1935. Embryological studies on the families Buxaceae, Meliaceae, Simaroubaceae, and Burseraceae. Ph.D. thesis, University of Lund, Lund.

How to cite this article:

Mousavi, F. Majd, A. 2019. The embryology of Ailanthus altissima (Simaroubaceae): an invasive species from Iran. Nova Biol. Reperta 6: 184-197.

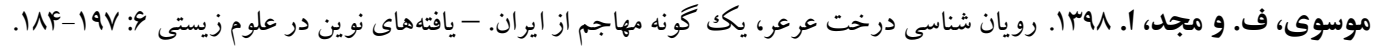

